\title{
Social wasp guild (Hymenoptera: Vespidae) visiting flowers in two of the phytophysiognomic formations: Riparian Forest and campos rupestres
}

\author{
${ }^{1}$ Ma Clemente, ${ }^{3}$ NR Campos, ${ }^{1} \mathrm{KM}$ Vieira, ${ }^{2} \mathrm{~K}$ Del-Claro, ${ }^{1} \mathrm{~F}$ Prezoto \\ 1 - Programa de Pós-Graduacão em Ciências Biológicas, Universidade Federal de Juiz de Fora, Minas Gerais, Brazil \\ 2 - Laboratório de Ecologia Comportamental e de Interações, Instituto de Biologia, Universidade Federal de Uberlândia, Minas Gerais, Brazil \\ 3 - Departamento de Biodiversidade, Evolução e Meio Ambiente - Instituto de Ciencias Exatas e Biologia - UFOP (DEBIO-ICEB_UFOP), MG, Brazil
}

\section{Article History \\ Edited by \\ Gilberto M. M. Santos, UEFS, Brazil \\ Received 17 January 2017 \\ Initial acceptance 02 March 2017 \\ Final acceptance 02 March 2017 \\ Publication date 21 September 2017}

\section{Keywords}

Trophic niche; pollinators; richness; abundance.

\section{Corresponding author:}

Mateus Aparecido Clemete

Universidade Estadual Paulista

Instituto de Biociências

Departamento de Zoologia

Avenida 24 A, no 1515

13506-900, Rio Claro -SP, Brasil

E-Mail: mateus1981@gmail.com

\begin{abstract}
Social wasps are part of the floral visitor guild. In this study, we investigated the distribution of flower-visiting wasp species in two phytophysiognomies in the State Park of Ibitipoca, Minas Gerais, Brazil. We inspected flowering plants with visiting wasps along a $1 \mathrm{~km}$ transect in riparian forest and another $1 \mathrm{~km}$ transect in campos rupestres over the course of one year, for a total sampling effort of 240 hours. We found a total of 103 individuals with 15 species distributed among 7 genera, the most common belonging to the Erythroxylaceae $(n=10)$ and Asteraceae $(n=10)$ families. Asteraceae had the highest abundance $(n=$ 55). The diversity and evenness of these insects was higher in riparian forest $\left(H^{\prime}=0.78\right.$ and $\left.J^{\prime}=0.75\right)$ than in campos rupestres $\left(H^{\prime}=0.30, J^{\prime}=0.39\right)$. All species visited flowers of 19 plant species in riparian forest, and eight wasp species visited 11 plant species in campos rupestres. These Polistinae acted as regular floral visitors, thus, conservation programs in these areas may be relevant for the maintenance of social wasp diversity.
\end{abstract}

\section{Introduction}

Social wasps belong to the order Hymenoptera and the family Vespidae, which is divided into six subfamilies. Polistinae contains 26 genera (Carpenter, 2004) and is the only eusocial subfamily, with occurrence throughout Brazil (Carpenter, 1993).

Social wasp surveys have been carried out in riparian forest (Souza et al., 2010; Pereira \& Aantonialli-Junior, 2011; Locher et al., 2014) and campos rupestres (Silva-Pereira \& Santos, 2006). However, studies that focus on the use of floral resources by wasps in the Neotropical region are scarce, particularly in these habitats. Social wasps constitute part of the floral visitor guild, and overlap with the bees in the exploitation of floral resources; they are thus a representative of the foragers (Heithaus, 1977 a, b; Santos et al., 2010; Melo et al., 2011). Male wasps, principally social wasps, are regular floral visitors that consume nectar and pollen, in addition to storing nectar for colonies (Gadagkar, 1991).

Riparian forest and campos rupestres are vegetation formations of extreme importance for conservation. The riparian forest study site is considered a Permanent Preservation Area (Conselho Nacional do Meio Ambiente - CONAMA, 2002) for protecting water resources and maintaining their quality in equilibrium with local flora and fauna (Lima \& Leopold, 1999). The campos rupestres site is protected due to high species richness (with many in the process of extinction) and endemism (Giulietti et al., 1997; Menezes \& Giulietti, 2000).

An accurate assessment of social wasp species acting as floral visitors and possible pollinators is fundamental for our knowledge of plant reproductive cycles in the study areas, and has implications for conservation of both plants and wasps. 
In this study we estimated the richness, diversity, abundance, niche amplitude, and evenness of social wasp floral visitors in riparian forest and campos rupestres in Ibitipoca State Park, Minas Gerais, Brazil.

\section{Material and methods}

The State Park of Ibitipoca has an area of 1,923 hectares and is located in the Serra de Ibitipoca in southeastern Minas Gerais, Brazil. The climate is characterized as Cwb according to the Köppen classification (humid mesothermic with dry winters and mild summers). The mean annual precipitation is approximately $1,532 \mathrm{~mm}$ and the mean annual temperature is $18.9^{\circ} \mathrm{C}$ (CETEC, 1983).

Social wasp collections were carried out in two of the phytophysiognomic formations present in Ibitipoca State Park: riparian forest and campos rupestres (sand land).

Riparian Forest- The phytophysiognomic profile of this area is transition between Cerrado de Altitude and Ombrophilic forest, which consists of a vegetational gradient that shifts from arbustive-arboreal physiognomy to predominantly arboreal (Rodela, 1998). The main plant families of the Ibitipoca State Park are Orchdaceae, Myrsinaceae, Melastomataceae, Bromeliaceae, Rubiaceae, Labiatae, Piperacea, Araceae, Passifloracea, Gesneriaceae, Polypodiaceae, Compositeae and Erythroxylaceae (Rodela, 1998).

Campos Rupestres- These areas present a xeromorphic physiognomy composed of a great diversity of herbaceous species, primarily represented by the families Orchidaceae, Poaceae, Asteraceae and Bromeliaceae, and shrub species, represented mainly by the Velloziaceae, Asteraceae, Melastomataceae and Asclepiadaceae, distributed across quartzitic outcrops (Rodela, 1998).

The study was carried out from November 2007 to October 2008, with one collection day per month per site taking place from 07:00 am to 05:00 pm. Total sampling effort was 240 hours. One transect of approximately one kilometer was established in each area, along which two observers surveyed plants on collection days. When wasps were observed foraging in the flowers, observers collected them using an entomological net and remained near the plant for ten minutes in case of arrival of new individuals (Aguiar, 2003; Lorenzon et al., 2003). Collected specimens were fixed in $70 \%$ alcohol and transported to the Laboratório de Ecologia Comportamental (LABEC) at the Universidade Federal de Juiz de Fora in Minas Gerais, Brazil. Specimens were identified using taxonomic keys for genus and species (Carpenter, 2004; Cooper, 1997; Carpenter \& Marques, 2001; Pickett \& Wenzel, 2007).

The plants visited by the wasps were described in the field according to floral characteristics, such as type of flower, color, and size. Date and collection location were recorded. Exsiccates from plant species visited by wasps were identified using keys for family and genus, and reviewed by
Professor Fátima Regina Gonçalves Salimena. We prepared a species list in alphabetical order of families and genera based on the Angiosperm Phylogeny Group III system (APG, 2009). Species nomenclature confirmed using the Brazilian Plant Species List (Jardim Botânico do Rio de Janeiro, 2012), the International Plant Names Index sites (INPI, 2016), and electronic databases of the Missouri Botanical Garden (MOBOT, 2016), the latter being also used to confirm nomenclature of exotic species.

The diversity and evenness of visiting social wasps in the hot-humid and cold-dry periods were calculated using the Shannon-Wiener Index (H'), (Shannon, 1948) in the PAST program (Hammer et al., 2001). Shannon-Wiener index (H') and evenness values were compared using a Mann-Whitney in BioEstat 4.0 (Freeware). Niche amplitude was calculated using the Shannon-Wiener Index ( $\left.\mathrm{H}^{\prime}\right)$ with the following formula:

$$
\mathrm{H}^{\prime}=-\Sigma \mathrm{pK} X \ln
$$

where $\mathrm{pK}$ is the proportion of individuals collected in plant $\mathrm{K}$, and $\ln$ is the logarithm of the $\mathrm{pK}$ value. Plant species visitation evenness for each wasp species was calculated using the following formula:

\section{J' = H' / H'max}

where H'max is the natural logarithm of the total number of plant species visited by wasp species. The values found for the Shannon-Wiener index $\left(\mathrm{H}^{\prime}\right)$ and evenness were compared using a Mann-Whitney test in BioEstat 4.0 (Freeware).

\section{Results and discussion}

A total of 103 individuals were collected, including 15 species distributed among seven genera. Wasps visited 27 plant species distributed among 14 families. The most important plant families for wasps were Erythroxylaceae $(\mathrm{n}=10)$, Asteraceae $(\mathrm{n}=10)$ and Rubiaceae $(\mathrm{n}=4)$, Malastomataceae $(\mathrm{n}=3)$, and Myrtaceae $(\mathrm{n}=3)$. The highest abundance of visiting social wasps was observed in Asteraceae with 55 individuals out 103 visiting this family, followed by Erythroxylaceae $(\mathrm{n}=14)$, Rubiaceae $(\mathrm{n}=10)$, Melastomataceae $(\mathrm{n}=5)$, Cunoniaceae, Myrtaceae $(\mathrm{n}=$ $4)$, Apocynaceae $(n=3)$ and Velloziaceae $(n=2)$. The families with only one visitor were Orquidaceae, Lythraceae, Fabaceae, Theaceae, Poaceae, and Ochnaceae, accounting for $55 \%$ of the foraging species during the entire collection period (Tables 1 and 2).

The diversity and evenness values for social wasp visits to flowers were higher in riparian forest $\left(\mathrm{H}^{\prime}=0.78\right.$, $\left.\mathrm{J}^{\prime}=0.75\right)$ than in campos rupestres $\left(\mathrm{H}^{\prime}=0.30, \mathrm{~J}^{\prime}=0.39\right.$ ), however the Shannon-Wiener indices for the two sites did not significantly differ $(\mathrm{Z}(\mathrm{U})=1.84(\mathrm{p})=0.064)$. There were 19 plant species visited by wasps in riparian forest, and all wasp visitor species were observed visiting all 19 plant species. The most abundant wasp species were Mischocyttarus confusus Zikán $1935(\mathrm{n}=16)$, Polybia occidentalis (Oliver) $(\mathrm{n}=14)$ 
Table 1: Numbers of social wasps collected while visiting plant species at the Ibitipoca State Park in riparian forest phytophysiognomy at the Ibitipoca State Park, Minas Gerais, Brazil. Collections took place from November 2007 to October 2008.

Plant Family/Species Social Wasp Species

Total

$\begin{array}{lllllllllllllll}\text { Amu } & \text { Apa } & \text { Ble } & \text { Mco } & \text { Mdr } & \text { Pbi } & \text { Pci } & \text { Pfe } & \text { Pac } & \text { Pfa } & \text { Pig } & \text { Ppa } & \text { Pse } & \text { Poc } & \text { Psy }\end{array}$

\begin{tabular}{|c|c|c|c|c|c|c|c|c|c|c|c|c|c|c|c|c|}
\hline \multicolumn{17}{|l|}{ Apocynaceae } \\
\hline Mandevilla sellowii & 0 & 0 & 0 & 0 & 1 & 0 & 0 & 0 & 0 & 0 & 0 & 0 & 0 & 0 & 0 & 1 \\
\hline Minaria acerosa & 0 & 0 & 0 & 0 & 1 & 0 & 0 & 0 & 0 & 0 & 0 & 0 & 0 & 0 & 1 & 2 \\
\hline \multicolumn{17}{|l|}{ Asteraceae } \\
\hline Inulopsis scaposa & 0 & 0 & 0 & 2 & 0 & 0 & 0 & 0 & 0 & 0 & 0 & 0 & 0 & 0 & 0 & 2 \\
\hline Mikania acuminata & 0 & 0 & 0 & 1 & 0 & 0 & 0 & 0 & 0 & 0 & 0 & 0 & 0 & 0 & 0 & 1 \\
\hline L. linearifolius* & 0 & 0 & 0 & 0 & 0 & 2 & 0 & 0 & 0 & 0 & 1 & 0 & 0 & 0 & 0 & 3 \\
\hline Baccharis crispa & 0 & 0 & 0 & 1 & 4 & 0 & 0 & 0 & 1 & 0 & 0 & 1 & 0 & 3 & 5 & 15 \\
\hline Senecio brasiliensis & 0 & 0 & 0 & 6 & 2 & 0 & 0 & 0 & 0 & 0 & 0 & 6 & 0 & 6 & 0 & 20 \\
\hline Baccharis rufidula & 1 & 0 & 0 & 1 & 1 & 0 & 0 & 0 & 0 & 0 & 0 & 3 & 0 & 1 & 0 & 7 \\
\hline
\end{tabular}

Cunoniaceae

W. paulliniifolia*

Erythroxylaceae

E. gonucladum*

$\begin{array}{lllll}0 & 0 & 0 & 0 & 0\end{array}$

0

Fabaceae

P. mediterranea*

Melastomataceae

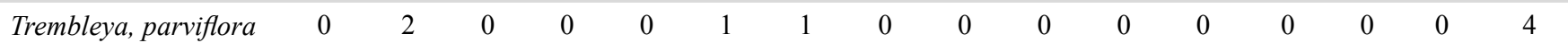

Myrtaceae

Eugenia acutata

$\begin{array}{llllll}0 & 0 & 0 & 0 & 0\end{array}$

0

0

$\begin{array}{lllllll}0 & 0 & 0 & 4 & 0 & 0 & 0\end{array}$

Orquidaceae

\begin{tabular}{|c|c|c|c|c|c|c|c|c|c|c|c|c|c|c|c|c|}
\hline P. pachysepala* & 0 & 0 & 0 & 0 & 0 & 0 & 0 & 0 & 0 & 0 & 0 & 0 & 0 & 0 & 0 & 0 \\
\hline \multicolumn{17}{|l|}{ Poaceae } \\
\hline Tristachya chrysothrix & 0 & 0 & 0 & 0 & 1 & 0 & 0 & 0 & 0 & 0 & 0 & 0 & 0 & 0 & 0 & 1 \\
\hline \multicolumn{17}{|l|}{ Rubiaceae } \\
\hline Posoqueria latifolia & 0 & 0 & 0 & 3 & 0 & 0 & 0 & 0 & 0 & 0 & 0 & 0 & 0 & 0 & 1 & 4 \\
\hline \multicolumn{17}{|l|}{ Theaceae } \\
\hline Laplacea fructicosa & 0 & 0 & 0 & 0 & 0 & 0 & 0 & 0 & 0 & 0 & 0 & 1 & 0 & 0 & 0 & 1 \\
\hline \multicolumn{17}{|l|}{ Velloziaceae } \\
\hline Barbacenia flava & 0 & 0 & 0 & 0 & 0 & 0 & 0 & 0 & 0 & 0 & 0 & 0 & 0 & 1 & 0 & 1 \\
\hline Vellozia albiflora & 0 & 0 & 1 & 0 & 0 & 0 & 0 & 0 & 0 & 0 & 0 & 0 & 0 & 0 & 0 & 1 \\
\hline Abundance & 1 & 2 & 1 & 16 & 11 & 4 & 1 & 2 & 2 & 1 & 3 & 16 & 2 & 14 & 7 & 83 \\
\hline
\end{tabular}

Abbreviations used for social wasp species. Amu= Agelaia multipicta, Apa $=$ Apoica pallens, Ble $=$ Brachgastra lecheguana $\mathbf{M c o}=$ Myschocyt tarus confusos, $\mathbf{M d r}=$ Mischocyttarus drewseni, $\mathbf{P b i}=$ Polistes billardieri $\mathbf{P c i}=$ Polistes cinerascens, $\mathbf{P f}=$ Polistes ferreri, $P$ Pac $=$ Polistes actaeon, $\mathbf{P f a}=$ Polybia fastidiosuscula, Pig $=$ Polybia ignobilis, Ppa $=$ Polybia paulista, $\mathbf{P s e}=$ Polybia sericea, Poc $=$ Polybia occidentalis, $\quad$ Psy= Protonectarina sylveirae; *Lessingianthus linearifolius; *Weinmannia paulliniifolia; *Erythroxylum gonucladum; *Periantra mediterranea; *Prosthechea pachysepala.

and Mischocyttarus drewseni Saussure $1857(\mathrm{n}=11)$, which were found foraging in eight, five, and seven plant species, respectively (Table 1). In the campos rupestres site eight social wasp species visited 11 plant species, with $P$. occidentalis (n $=7)$ and $M$. drewseni $(\mathrm{n}=6)$ having highest abundance and greatest diversity in resource use (visiting three and five plant species, respectively) (Table 2).

The diversity and evenness were higher in the hot-humid period (October-March) in riparian forest $\left(\mathrm{H}^{\prime}=0.83, \mathrm{~J}^{\prime}=0.73\right.$ ) and campos rupestres $\left(\mathrm{H}^{\prime}=0.73, \mathrm{~J}^{\prime}=0,62\right)$ than in the cold-dry period (April-September) $\left(H^{\prime}=0.31\right.$ and $H^{\prime}=0.21$, respectively), however Shannon-Weiner index values for hothumid versus cold-dry seasons did not differ in riparian forest $(\mathrm{Z}(\mathrm{U})=0.2402(\mathrm{p})=0.8102)$ or campos rupestres $(\mathrm{Z}(\mathrm{U})=$ $0.080(\mathrm{p})=0.936)$.

The amplitude of the trophic niche (H') varied from 0.63 to 2.34 (Table 3), with $M$. drewseni and M. confusus having highest values $\left(\mathrm{H}^{\prime}=2.34\right.$ and $\mathrm{H}^{\prime}=1$, respectively). 
Table 2: Numbers of social wasps collected while visiting plant species in campos rupestres phytophysiognomy at the Ibitipoca State Park, Minas Gerais, Brazil. Collections took place from November 2007 to October 2008.

\begin{tabular}{|c|c|c|c|c|c|c|c|c|c|}
\hline \multirow[t]{2}{*}{ Plant Family/Species } & \multicolumn{3}{|c|}{ Social Wasp Species } & \multirow[b]{2}{*}{$\mathrm{Pbi}$} & \multirow[b]{2}{*}{ Pfe } & \multirow[b]{2}{*}{ Ppa } & \multirow[b]{2}{*}{ Poc } & \multirow[b]{2}{*}{ Psy } & \multirow[t]{2}{*}{ Total } \\
\hline & Apa & Mco & $\mathrm{Mdr}$ & & & & & & \\
\hline \multicolumn{10}{|l|}{ Asteraceae } \\
\hline Chromolaena decumbens & 0 & 0 & 0 & 1 & 0 & 0 & 0 & 0 & 1 \\
\hline Lessingianthus linearifolius & 0 & 0 & 1 & 0 & 0 & 0 & 0 & 0 & 1 \\
\hline Mikania microdonta & 0 & 0 & 0 & 0 & 0 & 0 & 0 & 1 & 1 \\
\hline Baccharis crispa & 0 & 0 & 0 & 0 & 0 & 0 & 1 & 0 & 1 \\
\hline Eremanthus glomerulatus & 0 & 0 & 0 & 0 & 1 & 0 & 2 & 0 & 3 \\
\hline \multicolumn{10}{|l|}{ Lythraceae } \\
\hline Cuphea carthagenensis & 0 & 0 & 1 & 0 & 0 & 0 & 0 & 0 & 1 \\
\hline \multicolumn{10}{|l|}{ Melastomataceae } \\
\hline Tibouchina hieracioides & 0 & 0 & 1 & 0 & 0 & 0 & 0 & 0 & 1 \\
\hline \multicolumn{10}{|l|}{ Myrtaceae } \\
\hline Myrcia eriocalyx & 0 & 1 & 2 & 0 & 0 & 0 & 0 & 0 & 3 \\
\hline \multicolumn{10}{|l|}{ Ochnaceae } \\
\hline Ouratea semiserrata & 1 & 0 & 0 & 0 & 0 & 0 & 0 & 0 & 1 \\
\hline \multicolumn{10}{|l|}{ Orchidaceae } \\
\hline Prosthechea pachysepala & 0 & 0 & 1 & 0 & 0 & 0 & 0 & 0 & 1 \\
\hline \multicolumn{10}{|l|}{ Rubiaceae } \\
\hline Borreria capitata & 0 & 0 & 0 & 0 & 0 & 2 & 4 & 0 & 6 \\
\hline Abundance & 1 & 1 & 6 & 1 & 1 & 2 & 7 & 1 & 20 \\
\hline
\end{tabular}

Abbreviations used for social wasp species. Amu=Agelaia multipicta, Apa= Apoica pallens, Ble= Brachigastra lecheguana $\mathbf{M c o}=$ Myschocyttarus confusos, $\mathbf{M d r}=$ Mischocyttarus drewseni, $\mathbf{P b i}=$ Polistes billardieri $\mathbf{P} \mathbf{P} \mathbf{i}=$ Polistes cinerascens, $\mathbf{P} \mathbf{P} \mathbf{e}=$ Polistes ferreri, $\mathbf{P a c}=$ Polistes actaeon, $\mathbf{P f a}=$ Polybia fastidiosuscula, $\mathbf{P i g}=$ Polybia ignobilis, $\mathbf{P p a}=$ Polybia paulista, $\mathbf{P s e}=$ Polybia sericea, $\mathbf{P o c}=$ Polybia occidentalis, $\mathbf{P s y}=$ Protonectarina sylveirae.

Polistes ferreri, Apoica pallens (Fabricius, 1804), and Polybia ignobilis had the lowest value $\left(\mathrm{H}^{\prime}=0.63\right)$. M. drewseni visited the greatest number of plant species $(\mathrm{n}=12)$, but did not concentrate foraging on any particular species. Polybia occidentalis $\left(\mathrm{H}^{\prime}=1.78\right)$ also visited a significant number of plant species $(\mathrm{n}=7)$ and had the highest abundance $(\mathrm{n}=21)$ during the collection period. We note that half of all plant species sampled in this study $(\mathrm{n}=13)$ received a low number of individual visitors (from one to three). Nine wasp species $(60 \%)$ had low abundance in flowers, with only one to three individuals found in each study site.

The evenness of wasp visits ranged from 0.77 to 0.96 , with the lowest value found for Protonectarina sylveirae Saussure, $1854 ; 62.5 \%$ of all floral visits by this species were to Baccharia crispa (Asteraceae).

The higher species richness of social wasps visiting Asteraceae and Erythroxylaceae is partially explained by the fact that these botanical families are, according to Rodela (1998), widely distributed in riparian forests and campos rupestres at the Ibitipoca State Park. Wasps display opportunistic behavior, foraging in the most abundant resources to meet population resource demand (Raveret-Richter, 2000). Further, Asteraceae have a large number of small compressed flowers, called "brush- like" flowers, which provides easy access to floral resources (Proctor \& Lack, 1996; Cerana, 2004). These flowers produce a high abundance of nectar which is located only a few millimeters deep, and present shiny, yellow and white flowers that tend to attract insects (Faegri \& Pijl, 1979). Granja and Barros (1998) in a study in open Cerrado at the Reserva Ecológica da Fazenda Experimental of the University of Brasilia, found 14 species of wasps using Erythroxylaceae floral resources. The authors, as well as Amaral Jr. (1980), suggest that some Polybia and Polistes are effective pollinators of Erythroxylaceae due to their efficiency in contacting the stigmas. In the present study, Polistes billardieri Fabricius, 1804, Polybia ignobilis (Haliday, 1836), and Polybia sericea (Oliver, 1791) were found in Erythroxylum gonucladum, the only representative of the family Erythroxylaceae in either study area.

Niche amplitude values for $P$. ferreri, A. pallens (Fabricius) and P. ignobilis were low, indicating a narrow niche. This is reflected in the small number of floral resources used by these species and the small number of individuals. Variation in niche amplitude values among social wasps may be associated with factors that influence foraging activity (e.g., large differences in biomass), where greater values may indicate higher foraging capacity (Santos et al., 1998). 
Populations with higher biomass also use a greater amount of food resources (Santos et al., 2006). For example, in the current study Polybia occidentalis had the highest abundance of visiting individuals $(\mathrm{n}=21)$ and displayed a broad foraging spectrum, visiting nine plant species. Swarming wasps build large colonies that host many individuals, and the size of the colony can be the determining factor for resource consumption. This may affect foraging amplitude of these species through the influence of colony productivity on foraging activity (Spradbery, 1973).

The amplitude of a species trophic niche is an index subject to temporal and spatial changes, and may influence the degree of specialization (Camillo \& Garófalo, 1989). In Costa Rica, Heitaus (1977b) observed such variation in wasp species both among habitats and in the same habitat in different seasons. This author emphasizes the influence of plant flowering phenology on the abundance of floral resources and the strategy of resource exploration by visitors, which involves substitution of resources based on the quantity of food available. Flexibility in foraging behavior makes the amplitude of the trophic niche a dynamic variable in ecosystems. Wasp species with the highest evenness values with respect to plant visits frequently explored only one or two plant species, but also occurred in other species (Table 3 ). This generally agrees with the results of Heithaus (1977a) and Santos et al. (2006), who found that social wasp species are infrequent floral visitors, and that many plant species were visited by a small number of individuals.

Social wasp diversity was higher in the hot-humid period in both phytophysiognomies due to the increased biomass of plants and other insects (e.g., lepidopteran larvae), which provides more abundant supply of food (Souza \& Prezoto, 2006; Auad et al., 2010). The greater number of social wasp species visiting flowers in the riparian forest can be explained by vegetational heterogeneity in this environment, which generates higher niche complexity.

This forest formation in Ibitipoca is characterized by a sequence of shrub-tree species (predominantly trees) located near waterways (Rodela, 1998), an ideal location for wasp colony founding. In a study by Clemente et al.(2013) in the same site, riparian forest fostered a greater number of interactions between social wasp and plant species, providing support for the idea that vegetation complexity is positively correlated with social wasp diversity. The campos rupestres site showed lower species richness of social wasp floral visitors, likely due to having a less complex vegetation structure composed predominantly by herbaceous plants, grasses, and shrubs that are distributed among quartzite outcrops (Rodela, 1998). This area also has strong winds and a higher light incidence, which can lead to strong variation in microclimate (Elpino-Campos et al., 2007). Wasp-flower interactions in campos rupestres tend to be more specialized (Clemente et al., 2013), a situation that increases risk of species co-extinctions (Hernandes et al., 2004). Protonectarina sylveirae Saussure, 1854 , P. sericea, $P$. paulista, A. pallens, B. lecheguana, were among the social wasp species found in this environment. The occurrence of these species is unsurprising, as they are known to have high ecological tolerance (Clemente et al., 2013) and to be generally dominant in open ecosystems, thriving under severe environmental conditions. These and other highly tolerant species may thus be important for plant and insect community structure in harsh ecosystems such as campos rupestres. Santos et al. (2007) evaluated social wasp communities in mangrove, Atlantic forest and restinga, and found that wasp diversity was significantly (positively) correlated with plant diversity in each environment. The tropical Atlantic forest had the highest

Table 3: Amplitude and evenness of the trophic niche in social wasps collected in the Ibitipoca State Park, Lima Duarte, Minas Gerais, Brazil.

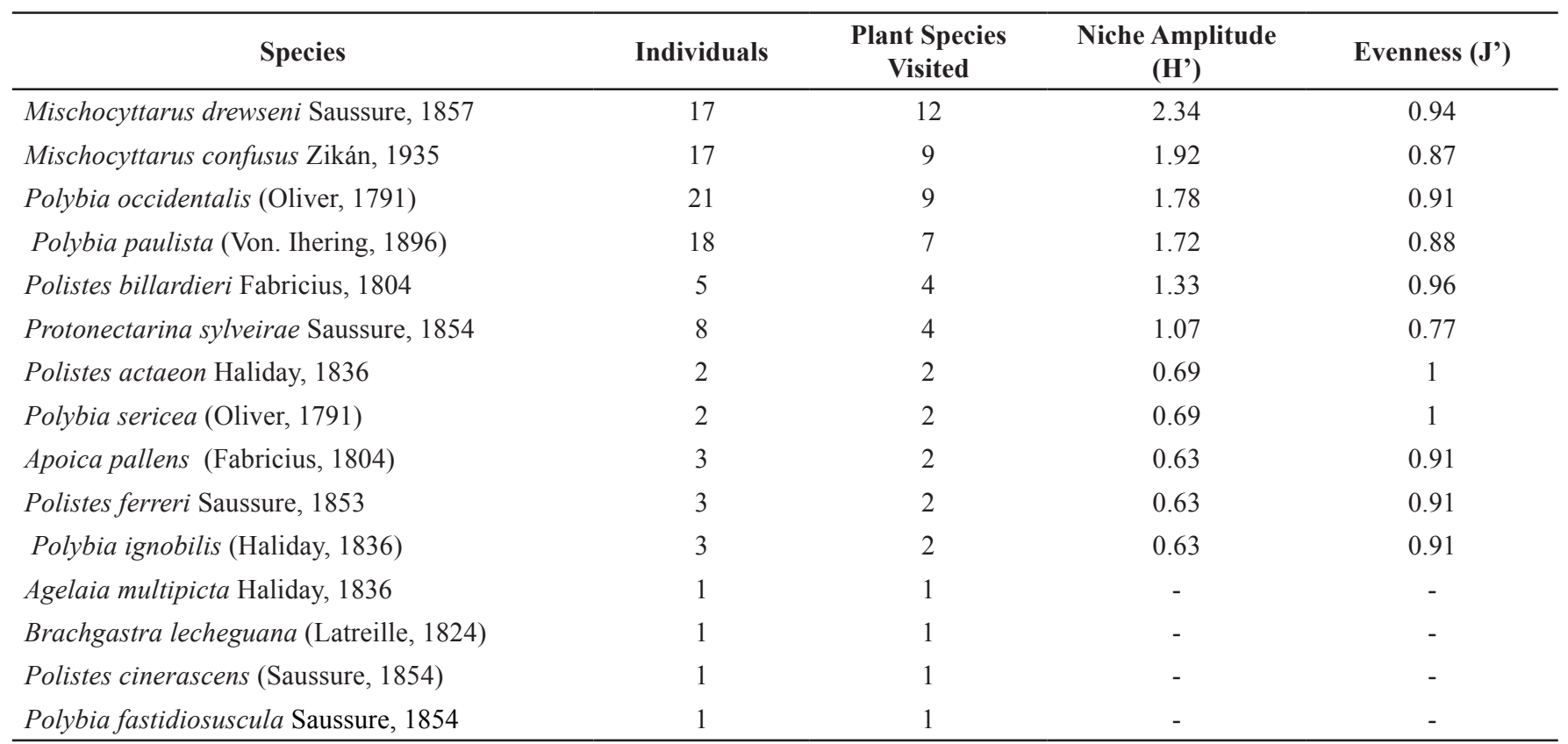


wasp richness (18 species), followed by restinga (16 species), and mangrove (eight species). Mangrove forest presents some ecological restrictions (i.e., salinity, temperature, and aridity) that can influence the diversity of wasps. Floristic composition, and vegetation structure and complexity are determinants of social wasp community composition and structure, directly influencing their fundamental and realized niches (Santos et al., 2007). Further, vegetation provides nesting substrate (Santos et al., 2006), carbohydrate resources (Santos et al., 1998), and materials for nest construction such as plant fibers (Rodrigues \& Machado, 1982; Marques \& Carvalho, 1993), and prey foraging area (Santos et al., 1998). Some wasp species only nest under certain structural conditions (e.g., open or closed physiognomies), and depend on specific plant morphological parameters (e.g., leaf shape and size, trunk diameter, presence of spines) (Henriques et al., 1992, Santos \& Gobbi, 1998; Cruz et al., 2006).

\section{Conclusion}

The Ibitipoca State Park contains various discrete vegetational profiles, and is composed by semi-deciduous forest and Cerrado species as well as endemic campos rupestres vegetation, typical of the rare and unique Brazilian montane savanna ecoregion. The flora of Ibitipoca provide diverse resources, favoring a rich fauna of social wasps. Although considered to be less effective compared to other pollinators in natural ecosystems, wasps did regularly visit flowers in the study areas. Thus, conservation of these areas may be relevant for the maintenance of social wasp diversity.

\section{Acknowledgments}

We would like to thank CNPq for the financial support (authors FP and KD), Profa. Dra. Fátima Salimena for identification of botanical material, IEF MG for providing the license and structural support. The Universidade Federal de Juiz de Fora provided financial assistance through a scholarship, and IBAMA ICMBIO provided the license for research.

\section{References}

Aguiar, C. M. (2003). Utilização de recursos florais por abelhas (Hymenoptera, Apoidea) em uma área de Caatinga (Itatim, Bahia, Brasil). Revista Brasileira de Zoologia, 20: 457-467.

Amaral Junior, A. (1980). Flora ilustrada catarinense: Eritroxiláceas. Itajaí: Herbário Barbosa Rodrigues.

APG III. 2009. An update of the Angiosperm Phylogeny Group classification for theorders and families of flowering plants: APG III. Botanical Journal of the Linnean Society 161: 105-121. doi: 10.1046/j.1095-8339.2003.t01-1-00158.x

Auad, A. M., Carvalho, C. A., Clemente, M. A. \& Prezoto, F. (2010). Diversity of Social Wasps (Hymenoptera) in a
Silvipastoral System. Sociobiology, 55: 627-636.

Barros, M. G. (1998). Sistemas reprodutivos e polinização em espécies simpátricas de Erythroxylum P. Br.(Erythroxylaceae) do Brasil. Brazilian Journal of Botany, 21: 159-166. doi: 10.1590/S0100-84041998000200008

Camillo, E. \& Garófalo, C. A. (1989). Analysis of the niche of two sympatric species of Bombus (Hymenoptera, Apidae) in southeastern Brazil. Journal of Tropical Ecology, 5: 81-92. doi: $10.1017 / \mathrm{S} 0266467400003242$

Carpenter, J. M. (1993). Biogeographic patterns in the Vespidae (Hymenoptera): two views of Africa and South America. Biological relationships between Africa and South America, 139-155.

Carpenter, J. M \& Marques, O. M. (2001). Contribuição ao estudo dos vespídeos do Brasil (Insecta, Hymenoptera, Vespoidea, Vespidae). Cruz das Almas, Universidade Federal da Bahia. Publicações Digitais, 2

Carpenter, J. M. (2004). Synonymy of the genus Marimbonda Richards, 1978, with Leipomeles Möbius, 1856 (Hymenoptera: Vespidae; Polistinae), and a new key to the genera of paper wasps of the New World. American Museum Novitates, 3465: 1-16.

Cerana, M. M. (2004). Flower morphology and pollination in Mikania (Asteraceae). Flora-Morphology, Distribution, Functional Ecology of Plants, 199: 168-177. doi: 10.1078/ 0367-2530-00145

CETEC. (1983). Diagnóstico Ambiental de Minas Gerais. CETEC. Belo Horizonte: Fundação Centro Tecnológico de Minas Gerais/CETEC. Série de Publicações Técnicas/SPT010.

Conselho Nacional do Meio Ambiente. Resolução no 303, de 20 de março de 2002. Dispõe sobre parâmetros, definições e limites de Áreas de Preservação Permanente. Brasília, 2002. Disponível em: $<$ http://www. mma.gov.br>. Acesso em: 5 abr. 2008.

Cooper, M. (1997). The subgenus Megacanthopus Ducke of Mischocyttarus de Saussure (Hym., Vespidae), with a key and three new species. Entomologist's Monthly Magazine, 133: 217-223.

Clemente, M.A., Lange, D., Dáttilo, W., Del-Claro, K. \& Prezoto, F. (2013). Social wasp-flower visiting guild interactions in less structurally complex habitats are more susceptible to local extinction. Sociobiology, 60: 337-344. doi: 10.13102/sociobiology.v60i3.337-344

Da Cruz, J. D., Giannotti, E., Santos, G. M., Bichara Filho, C. C., \& Da Rocha, A. A. (2006). Nest site selection and flying capacity of neotropical wasp Angiopolybia pallens (Hymenoptera: Vespidae) in the Atlantic Rain Forest, Bahia State, Brazil. Sociobiology, 47(3), 739-749.

Elpino Campos, A., Del Claro, K. \& Prezoto, F. (2007). Diversity of social wasps (Hymenoptera: Vespidae) in 
Cerrado fragments of Uberlândia, Minas Gerais State, Brazil. Neotropical Entomology, 36: 685-692. doi: 10.1590/S1519566X2007000500008

Faegri, K. \& Vander Pijl, L. (1979). The principles of pollination ecology, Pergamon Press. Inc., Elmsford, New York.

Gadagkar, R. (1991). Belonogaster, Mischocyttarus, Parapolybia and independent-founding Ropalidia. The social biology of wasps, 149-190.

Giulietti, A. M, Pirani, J. R. \& Harley, R. M. (1997). Espinhaço range region, eastern Brazil. Centres of plant diversity: a guide and strategy for their conservation, 3: 397-404.

Gottsberger, G. \& Silberbauer- Gottsberger, I. (1988). Evolution of flower structures and pollination in Neotropical Cassiinae (Caesalpiniaceae) species. Phyton (Austria), 28: 293-320.

Hammer, O., Harper, D.A.T. \& Ryan, P. D. (2001). PAST: Paleontological Statistics software package for education and data analysis. Palaeontologia Electronica. 4: 1-9.

Heithaus E. R. (1977a). Flower-feeding specialization in wild bee and wasp communities in seasonal neotropical habitats. Oecologia, 42: 179-194. doi: 10.1007/BF00344856

Heithaus, E. R. (1977b). Community structure of neotropical flower visiting bees and wasps: diversity and phenology. Ecology, 60: 190-202. doi: 10.2307/1936480

Henriques, R. P. B., Rocha, I. R. D. \& Kitayama, K. (1992). Nest density of some social wasp species in Cerrado Vegetation of Central Brazil (Hymenoptera: Vespidae). Entomologia Generalis, 17: 265-268. doi: 10.1127/entom. gen/17/1992/265

Hermann, G. (2007). Plano de manejo do Parque Estadual do Ibitipoca. Instituto Estadual de Florestas, MG. [Relarótio Técnico não publicado]. Valor Natural, Belo Horizonte, MG.

Hermes, M. G. \& Köhler, A. (2006). The flower-visiting social wasps (Hymenoptera, Vespidae, Polistinae) in two areas of Rio Grande do Sul State, southern Brazil. Revista Brasileira de Entomologia, 50: 68-274. doi: 10.1590/S008556262006000200008

Hernandes, J. L., Pedro Júnior, M. J. \& Bardin, L. (2004). Variação estacional da radiação solar em ambiente externo e no interior de floresta semidecídua. Revista Árvore, 28: 167-172.

Jardim Botânico do Rio de Janeiro. Lista de espécies da flora do Brasil. (2016). Disponível<http://floradobrasil.jbrj.gov. br/jabot/listaBrasil/PrincipalUC/PrincipalUC.do;jsessionid $=46 \mathrm{E} 171670 \mathrm{DCD} 5 \mathrm{FC} 3 \mathrm{~F} 924 \mathrm{~F} 90 \mathrm{BEC} 719 \mathrm{E} 94>$. Acesso em janeiro de 2016.

Lima, P. R. A., \& Leopoldo, P. R. (1999). Interceptação de chuva por mata ciliar naregião central do Estado de São Paulo. Energia na Agricultura, 14: 25-33.

Locher, G. A., Togni, O. C., Silveira, O. T., \& Giannotti
E. (2014). The social wasp fauna of a riparian forest in southeastern Brazil (Hymenoptera, Vespidae). Sociobiology, 61: 225-233. doi: 10.13102/sociobiology.v61i2.225-233

Lorenzon, M. C., Matrangolo, C. A., \& Schoereder, J. H. (2003). Flora visited by the eusocial bees (Hymenoptera, Apidae) in a savanna of the south of Piaui, Brazil. Neotropical Entomology, 32: 27-36. doi: 10.1590/S1519566X2003000100004

Marques, O. M. (2007). Diversity and community structure of social wasps (Hymenoptera: Vespidae) in three ecosystems in Itaparica island, Bahia state, Brazil. Neotropical Entomology, 36: 180-185. doi: 10.1590/S1519-566X2007000200002

Mello, Marco A.R. ; Santos, G.M.de M. ; Mechi, M. R. ; Hermes, M. G. . High generalization in flower-visiting networks of social wasps. Acta Oecologica (Montrouge), 37 : 37-42, 2011. doi: 10.1016/j.actao.2010.11.004

Menezes, N. X \& Giulietti, A. M. (2000). Campos rupestres In: Mendonça, M. P, \& Lins, L. V (2000). Lista vermelha das espécies ameaçadas de extinção da flora de Minas Gerais. Fundação Biodiversitas, Fundação Zoobotânica de Belo Horizonte, Belo Horizonte, p. 65-73.

Missouri Botanical Garden's VAST (Vascular Tropicos) nomenclatural database and associated authority files. Disponível em: <http://mobot.mobot.org/W3T/Search/vast. html>. Acesso em janeiro, 2016.

Pereira, M. D. G. C. \& Aantonialli Junior, W. F. (2011). Social wasps in riparian forest in Batayporã, Mato Grosso do Sul state, Brazil. Sociobiology, 57: 153-163.

Pickett, K. M. \& Wenzel, J. W. (2007). Revision and Cladistic Analysis of the Nocturnal Social Wasp Genus, Apoica Lepeletier (Hymenoptera: Vespidae; Polistinae, Epiponini). American Museum Novitates, 3562: 1-30.

Proctor, M., Yeo, P. \& Lack,A. (1996). The natural history of pollination. Harper Collins Publishers.

Richter, M. R. (2000). Social wasp (Hymenoptera: Vespidae) foraging behavior. Annual review of entomology, 45: 121150. doi: 10.1146/annurev.ento.45.1.121

Rodela, L. G. (1998). Cerrados de altitude e campos rupestres do Parque Estadual do Ibitipoca, sudeste de Minas Gerais: distribuição e florística por subfisionomias da vegetação. Revista do Departamento de Geografia, 12: 163-189. doi: 10.7154/RDG.1998.0012.0007

Rodrigues, V. M., \& Machado, V. L. L. (1982). Vespídeos sociais: espécies do Horto Florestal Navarro de Andrade, Rio Claro, SP. Naturalia, 7: 173-175.

SANTOS, G. M. de M.; Aguiar, Cândida M. Lima ; Mello, Marco A.R. . Flower-visiting guild associated with the Caatinga flora: trophic interaction networks formed by social bees and social wasps with plants. Apidologie (Celle). 41: 
466-475, 2010. doi:10.1051/apido/2009081

Santos, G. M. D., \& Gobbi, N. (1998). Nesting habits and colonial productivity of Polistes canadensis canadensis (L.) (Hymenoptera-Vespidae) in a Caatinga area, Bahia State Brazil. Journal of Advanced Zoology, 19: 63-69.

Santos, G. M. D., Aguiar, C. M., \& Gobbi, N. (2006). Characterization of the social wasp guild (Hymenoptera: Vespidae) visting flowers in the caatinga (Itatim, Bahia, Brazil). Sociobiology, 47: 483-494.

Santos, G. M. D., Bichara Filho, C. C., Resende, J. J., Cruz, J. D. D., \& Marques, O. M. (2007) Diversity and community structure of social wasps (Hymenoptera: Vespidae) in three ecosystems in Itaparica island, Bahia state, Brazil. Neotropical Entomology, 36: 180-185.

Shannon, C. E. (1948). The mathematical theory of communication, p. 3-91. In: C.E. Shannon \& W. Weaver (Eds). The mathematical theory of communication. Urbana, University Illinois Press, 117p.

Silva-Pereira, V. D., \& Santos, G. M. M (2006). Diversity in bee (Hymenoptera: Apoidea) and social wasp (Hymenoptera: Vespidae, Polistinae) community in" campos rupestres", Bahia, Brazil. Neotropical Entomology, 35: 165-174. doi: 10.1590/S1519-566X2006000200003
Somavilla, A. \& Köhler, A. (2012). Preferência floral de vespas (Hymenoptera: Vespidae) no Rio Grande do Sul, Brasil. Entomobrasilis, 5: 21-28. doi: 10.12741

Souza, M. M., Ladeira, T. E., Assis, N. R. G. A., ElpinoCampos, A., Carvalho, P., \& Louzada, J. N. (2010). Ecologia de vespas sociais (Hymenoptera, Vespidae) no Campo Rupestre na Área de Proteção Ambiental, APA, São José, Tiradentes, MG. MG Biota, 3: 15-30.

Souza, M. M. \& F. Prezoto (2006). Diversity of social wasps (Hymenoptera: Vespidae) in semideciduous forest and cerrado (Savanna) regions in Brazil. Sociobiology, 47: 135-147.

Spradebery, J. P. (1973). Wasps: An account of the biology and natural history of social and solitary wasps. University of Washington Press. 408 p.

Stehmann, J. R. (2009). Plantas da floresta atlântica (Vol. 1). Rio de Janeiro: Jardim Botânico do Rio de Janeiro.

IPNI - The International Plant Names Index. The international plant names index database. Disponível em: <http:/www. ipni.org/index.html $>$. Acesso em janeiro 2016.

Vogel, S. (1954). Blütenbiologische Typen als Elemente der Sippengliederung dargestellt anhand der Flora Südafrikas. Jena, Gustav Fischer Verlag, 338 p. 